\title{
THE APPLICATION OF SATELLITE TECHNOLOGY IN THE STUDY OF GEODYNAMIC MOVEMENTS IN THE WIDER ZAGREB AREA
}

\author{
Boško Pribičević, Almin Đapo, Marin Govorčin
}

Original scientific paper Recognizing the fact that the region around the capital belongs seismically in one of the most vulnerable areas in the Republic of Croatia, the interdisciplinary geodynamic research was initiated which lasts for 18 years now. Since the establishment of the geodynamic network, ten series of precise GPS measurements on specially stabilized points of the geodynamic network were conducted in order to determine tectonic movements and related seismic activities in the wider Zagreb area. From all conducted measurements in the period from 1997 to 2015 , the original geodetic model of tectonic movements was created. Following the analysis of geodetic and geological data, a unique interdisciplinary surface layers movement model of the research area was determined. During 2015, PSInSAR (Persistent Scatterer InSAR) technology was included in the research and was combined with the GPS measurements. The paper describes the combination of these two methods for the period $2004 \div 2009$ which resulted in denser and more reliable movement model in the urban part of the research area, especially in its height component, which is very important for the safety of buildings.

Keywords: geodynamics; GPS measurements; PSInSAR; tectonic movement; Zagreb

\section{Primjena satelitskih tehnologija u istraživanju geodinamičkih pomaka na širem zagrebačkom području}

Izvorni znanstveni članak

Uvažavajući činjenicu da šire zagrebačko područje spada seizmički u jedno od najugroženijih područja u Republici Hrvatskoj, započeta su predmetna interdisciplinarna geodinamička istraživanja koja traju punih 18 godina. Od uspostave geodinamičke mreže provedeno je deset serija preciznih GPS mjerenja na specijalno stabiliziranim točkama predmetne mreže u svrhu određivanja pomaka odnosno tektonskih pokreta i srodnih seizmičkih aktivnosti na širem zagrebačkom području. Iz svih provedenih mjerenja od 1997. do 2015. godine stvoren je originalni geodetski model tektonskih pomaka. Provedenom analizom geodetskih i geoloških podataka, kao rezultat je određen jedinstveni interdisciplinarni model gibanja pripovršinskih slojeva na području istraživanja.Tijekom 2015. godine u istraživanje je uključena PSInSAR (Persistent Scatterer InSAR) tehnologija koja je kombinirana sa GPS mjerenjima. U radu je prikazana kombinacija ovih dviju metoda za period $2004 . \div 2009$. te je rezultirala puno gušćim i još vjerodostojnijim modelom pomaka u izgrađenom dijelu područja istraživanja, i to posebice u njegovoj visinskoj komponenti, što je posebno važno za sigurnost građevina.

Ključne riječi: geodinamika; GPS mjerenja; PSInSAR; tektonika; Zagreb

\section{Introduction}

This paper is the result of integrating all of the collected data from eighteen years' research of interdisciplinary scientific team which focused on the monitoring and study of geodynamic processes of the wider area of the City of Zagreb. During the planning of the included areas of research the size and spatial extension of the City of Zagreb and other interdisciplinary aspects were taken into account so that the total area which respective geodynamic studies included is about $800 \mathrm{~km}^{2}$.

The main objective of the underlying geodynamic research is to determine the actual geodynamic movements with very high accuracy over a long period of time. In order to represent geodynamic events in the area of research in the best way, Geodynamic Network was designed and established in 1997 with an initial total of 43 specially stabilized points $[1,2]$.

GPS technology in the last twenty years has established itself as a major geodetic contribution to the geodynamic research [3], and the establishment of the respective geodynamic network, in 1997, opened the space for development of the geodynamic project to monitor tectonic movements in the Zagreb mountain Medvednica and boundary areas of several important tectonic units that meet in the wider Zagreb area [4, 5]. On one side are the branches of the southeast Alps, on the other side the Dinarides, and on the third side is the Pannonian Basin. In the research area numerous important faults stand out along which tectonic activity determines the number and intensity of earthquakes [6, 7]. GPS measurement campaigns on Geodynamic network were conducted ten times in total in the period from 1997 to 2015, which represent a set of measured data, which is used for the determination of geodynamic movements in the network [8].

Since in the wider Zagreb area within the underlying research, a full range of geological measurements was conducted too, a scientific comparison of the two models was realized by independent methods: geodetic model, based on the precise GPS measurements and geological model, based on long-term geological research, were performed.

Therefore, scientifically-based testing and analysis of correlation between the geodetic and geological models is carried out in order to create a unique interdisciplinary movement model in the wider Zagreb area [8].

Data from GPS measurements conducted on the points of the geodynamic network in the period from 1997 to 2015, have been processed in the scientific software GAMIT/GLOBK, which is designed specifically for processing of GPS measurements in geodynamic networks. GAMIT/GLOBK calculates the velocities on the points by applying modern methods of Kalman filtering [11].

The result are the velocity models on the points of the geodynamic network for the periods between the individual campaigns, and cumulatively for the whole period from 1997 to 2015 . Also the interpolation of the velocity values obtained for the entire period of research by IDW (Inverse Distance Weighting) method was 
performed with the inclusion of the Zagreb area fault model. In the end the original geodetic model of velocity field for the whole research area was created.

The research was extended by including the SAR (Synthetic Aperture Radar) technology. The reasons for the use of this technology in the field of geodynamic research are tremendous technological advances in the collection, as well as data processing and large coverage of the observations. Namely, it is the application of radar technology from space to obtain a digital representation of the configuration of the ground on which the periodic observations can detect changes with millimeter accuracy. As part of the research, 40 satellite (Envisat) radar images for the period 2004 $\div 2009$ were processed. During the processing of images, interferometric method PSInSAR (Persistent scatterer Interferometry) was applied which resulted with the denser and more credible model of the movements in the urban areas of research, in particular in its height component, which is especially important for the safety of buildings. It's worth noting that the SAR observations were combined with the GPS measurements, and the reason for defining the aforementioned observation period $(2004 \div 2009)$ was in high representation of the GPS campaigns in that period (2004, 2006, 2007, 2008 and 2009). The GPS data enable precise determination of horizontal and vertical movements on discrete points while the SAR data provide precise vertical movements over large areas with a temporal resolution of one month. By combining these two methods the accurate and detailed perception of geodynamic activities in the area of research with a focus on urban areas is acquired.

\section{Conducted GPS measurements, processing and results}

Research on the Geodynamic Network of the City of Zagreb began in 1997 and so far during the eighteen years, ten GPS campaigns were carried out in order to determine the geodynamic movements on the network points.

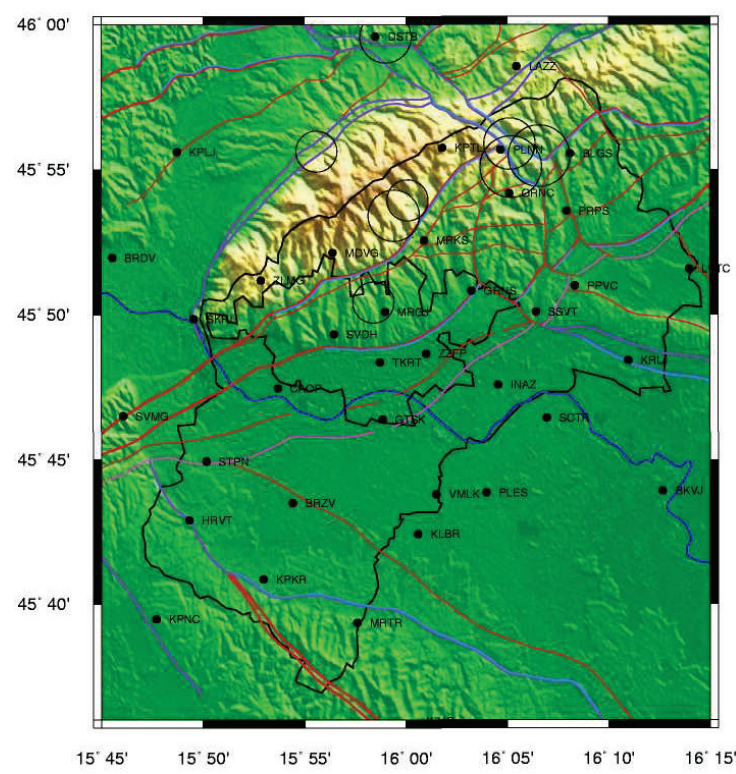

Figure 1 Geodynamic network with marked major faults and epicenters of earthquakes.
A total of ten GPS campaigns was conducted: 1997 , 2001, 2003, 2004, 2005, 2006, 2007, 2008, 2009 and 2015. Only seven out of ten of those measurement campaigns cover all of the points of the Network, as follows: 1997, 2001, 2004, 2006, 2008, 2009 and 2015 (41 point). Two of the campaigns were carried out with the aim of surveying on densification points 2005 and 2007 (11 and 21 points) $[1,8]$. Tab. 1 shows all conducted campaigns including the number of sessions, points included and receivers used. Fig. 1 shows the respective network with the most important faults and epicenters of earthquakes plotted.

All conducted GPS measurements on the Geodynamic Network of the City of Zagreb were processed in the same way, by using the latest version of the scientific GPS software GAMIT/GLOBK ver. 10.6 which runs under the Linux operating system. GAMIT/GLOBK uses Kalman filter to determine the velocities from the discrete GPS campaigns. This software gives multipoint solutions, therefore, all the point velocities are processed at once and the covariance matrix is common to the entire network [11].

All GAMIT parameters are set for regional or local campaign. For the reference of the geodynamic network two points were selected: the city's permanent GPS stations, CAOP 1038 , because it is the most stable point in the City of Zagreb and in addition the city permanent GPS station, and point ZZFP 1039. Referent points also had the possibility of relative movement, but have proven to be very stable. Shifts of all other points in the network refer to the vector between the two points mentioned. In this way, the possibility of overestimating the movement of all points in the network due to possible movement of a unique origin was avoided.

Table 1 All conducted GP campaigns with number of sessions, points included and used receivers

\begin{tabular}{|c|c|c|c|c|}
\hline Campaign & Date & $\begin{array}{c}\text { Nr. } \\
\text { sesion }\end{array}$ & $\begin{array}{c}\text { Nr. } \\
\text { Pts }\end{array}$ & $\begin{array}{c}\text { Nr. } \\
\text { GPS }\end{array}$ \\
\hline Zagreb 1997 & $27.10 .1997-29.10 .1997$ & 2 & 43 & 27 \\
\hline Zagreb 2001 & $25.06 .2001-28.06 .2001$ & 3 & 40 & 16 \\
\hline Zagreb 2003 & $22.06 .2003-23.06 .2003$ & 1 & 13 & 13 \\
\hline Zagreb 2004 & $17.06 .2004-20.06 .2004$ & 3 & 39 & 13 \\
\hline Zagreb 2005 & $10.09 .2005-11.09 .2005$ & 1 & 11 & 11 \\
\hline Zagreb 2006 & $22.06 .2006-25.06 .2006$ & 3 & 41 & 15 \\
\hline Zagreb 2007 & $13.07 .2007-15.07 .2007$ & 2 & 21 & 13 \\
\hline Zagreb 2008 & $10.06 .2008-13.06 .2008$ & 3 & 41 & 15 \\
\hline Zagreb 2009 & $11.06 .2009-14.06 .2009$ & 3 & 41 & 15 \\
\hline Zagreb 2015 & $11.06 .2015-14.06 .2015$ & 3 & 41 & 15 \\
\hline
\end{tabular}

Point velocities were calculated using GLOBK modules, where the velocity field was calculated using a method of Kalman filtering $[9 \div 15]$. Velocities are expressed in millimeters per year $(\mathrm{mm} / \mathrm{yr})$. Also the magnitude of the total spatial vector was calculated in all three dimensions.

Tab. 2 provides the statistical absolute values of cumulative annual velocity of network points for the period $2004 \div 2009$. To obtain a cumulative model of velocities of points of the observed area for the entire period from 2004 to 2009 , in further processing of the data it was necessary to combine the resulting solution of each individual campaign.

The first two columns show the velocity as a component of latitude and longitude $\left(v_{\varphi}\right.$ and $\left.v_{\lambda}\right)$ the third 
column is the resultant of the first and second component (horizontal velocity $-v_{\text {hor }}$ ), the last column is the vertical velocity component $\left(v_{\text {ver }}\right)$.

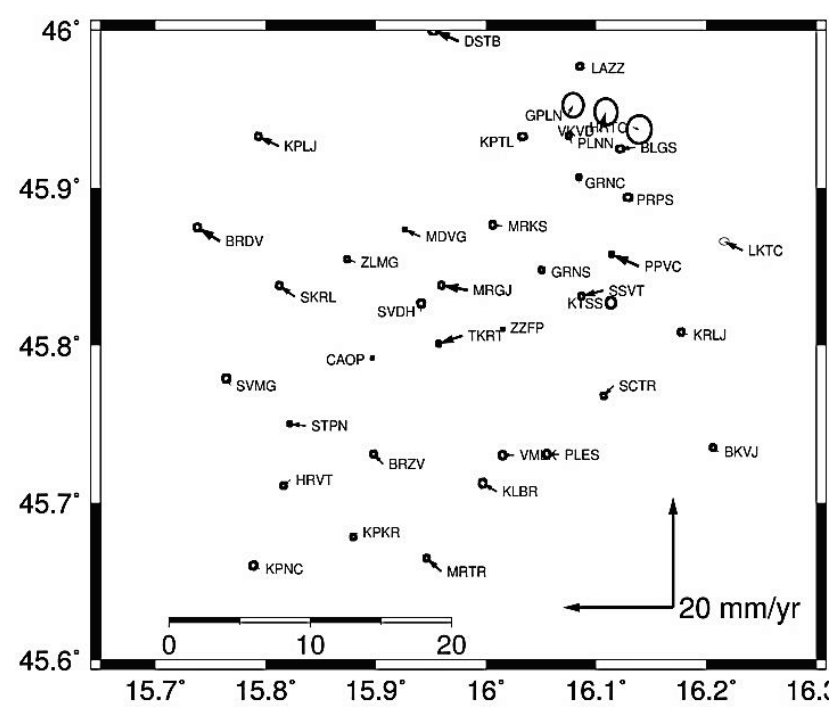

Figure 2 Cumulative velocities on the network points for the period from 2004 to 2009

Fig. 2 shows the cumulative solution of the point velicities of the Network points obtained for the period observed from 2004 to 2009.

Absolute velocity values for the cumulative solution in horizontal direction are $5,4 \mathrm{~mm} / \mathrm{yr}$ and in vertical 21,1 $\mathrm{mm} / \mathrm{yr}$. Computed cumulative solution is used for creating the geodetic model of tectonic movements and in the combination with geologic data for the creation of the original movement model of the Earth's crust surface on the wider Zagreb area.

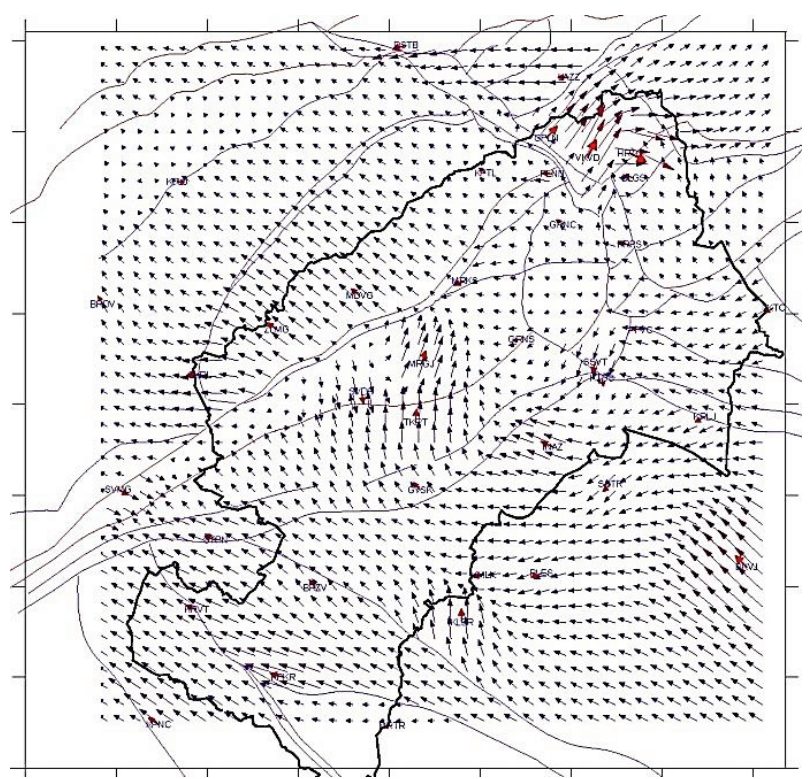

Figure 3 Geodetic velocity model computed using IDW interpolation with inclusion of the foult model of the wider Zagreb area

Table 2 Statistical overview of the absolute values of the annual velocities of the points for the period from 1997 to 2009

\begin{tabular}{|c|c|c|c|c|}
\hline & $v_{\varphi}(\mathrm{mm} / \mathrm{yr})$ & $v_{\lambda}(\mathrm{mm} / \mathrm{yr})$ & $v_{\text {hor }}(\mathrm{mm} / \mathrm{yr})$ & $v_{\text {ver }}(\mathrm{mm} / \mathrm{yr})$ \\
\hline Min & 0,0 & 0,1 & 0,4 & 0,0 \\
\hline Max & 3,5 & 4,9 & 5,4 & 21,1 \\
\hline Avg & 1,1 & 1,9 & 2,4 & 4,0 \\
\hline
\end{tabular}

\section{Synthetic Aperture Radar Interferometry (InSAR)}

Synthetic Aperture Radar Interferometry (InSAR), also referred to as SAR (Synthetic Aperture Radar) interferometry is one of the radar based techniques used in geodesy, as a part of remote sensing techniques. The InSAR technique exploits two or more SAR images to measure the signal phase changes, or interference over time. Results are interferograms, which can be used for monitoring different geophysical and surface processes occurring on the Earth's surface, such as earthquakes, vulcanic eruptions, landslide, uprising and subsidence events, glacial movements and etc. Moreover, with this technique, it is possible to achieve a determination of ground surface deformations with sub-centimeter accuracy, over an area of interest in period of a few days to several years.

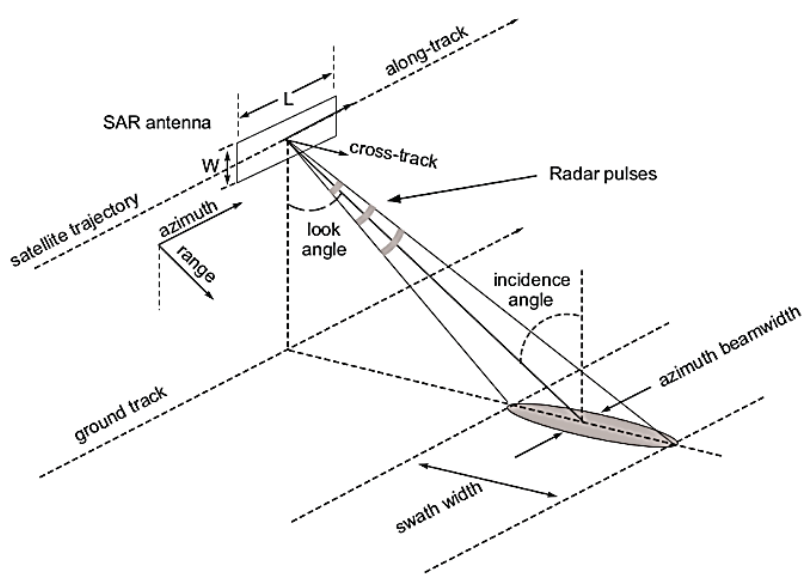

Figure 4 SAR acquisition geometry [16]

Synthetic Aperture Radar is an active radar imaging system usually located on the moving platforms (airplanes, satellites), which are flying over and mapping the areas of interest. The SAR systems are side-looking imaging systems and the geometry of the data acquisition is shown in Fig. 4. This imaging system represents one of the active remote sensing techniques, where the SAR antenna emits and receives the backscattered radar signals (electromagnetic radiation of the objects)(Fig. 5).
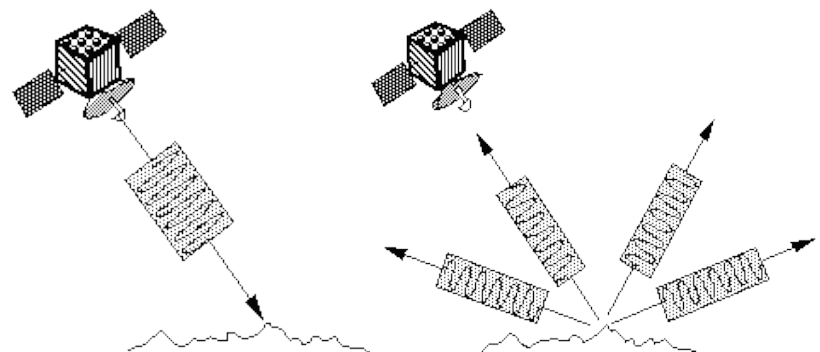

Figure 5 Emitting and receiving backscattered electromagnetic radiation

[17]

The most common SAR platforms are satellites equipped with SAR sensors orbiting the Earth on a nearpolar orbit at an altitude ranging from 500 to $800 \mathrm{~km}$ above the Earth's surface [18]. Satellite missions equipped with SAR sensors and their main characteristics are shown in Tab. 3. 
Table 3 Satellite missions equipped with SAR sensors

\begin{tabular}{|c|c|c|c|c|c|}
\hline Satellite & $\begin{array}{l}\text { Band and signal } \\
\text { wavelength }(\mathrm{cm})\end{array}$ & $\begin{array}{c}\text { Max spatial } \\
\text { resolution }(\mathrm{m})\end{array}$ & Polarisation & $\begin{array}{l}\text { Max. temporal } \\
\text { resolution (days) }\end{array}$ & State, yr. of launch \\
\hline Sentinel-1 & C-band $-5,6$ & 5 & $\mathrm{HH}, \mathrm{VV}, \mathrm{HV}, \mathrm{VH}$ & 6 & Europe 2014 \\
\hline ALOS-2 & L-band $-23,5$ & 3 & $\mathrm{HH}, \mathrm{VV}, \mathrm{HV}, \mathrm{VH}$ & 14 & Japan 2014 \\
\hline CosmoSkymed & X-band -3 & 1 & $\mathrm{HH}, \mathrm{VV}, \mathrm{HV}, \mathrm{VH}$ & 16 & Italy 2007 \\
\hline TerraSAR-X & X-band -3 & 1 & $\mathrm{HH}, \mathrm{VV}, \mathrm{HV}, \mathrm{VH}$ & 11 & Germany, 2007 \\
\hline Radarsar- 2 & C-band $-5,6$ & 3 & $\mathrm{HH}, \mathrm{VV}, \mathrm{HV}, \mathrm{VH}$ & 24 & Canada 2007 \\
\hline ALOS & L-band $-23,5$ & 10 & $\mathrm{HH}, \mathrm{VV}, \mathrm{HV}, \mathrm{VH}$ & 46 & Japan 2006 \\
\hline Envisat & C-band $-5,6$ & 23 & $\mathrm{HH}, \mathrm{VV}, \mathrm{HV}, \mathrm{VH}$ & 35 & Europe 2002 \\
\hline Radarsat & C-band $-5,6$ & 8 & $\mathrm{HH}$ & 24 & Canada 1995 \\
\hline ERS-2 & C-band $-5,6$ & 23 & $\mathrm{VV}$ & 35 & Europe 1995 \\
\hline ERS-1 & C-band - 5,6 & 23 & $\mathrm{VV}$ & 35 & Europe 1991 \\
\hline
\end{tabular}

The angle between satellites orbit and true NorthSouth varies slightly depending on the satellite but, in general lies in the range of $10^{\circ}$. Furthermore, satellites are orbiting around the Earth in two directions; from the North to the South Pole (descending orbit) and back, from the South to the North Pole (ascending orbit) (Fig. 6) [18].

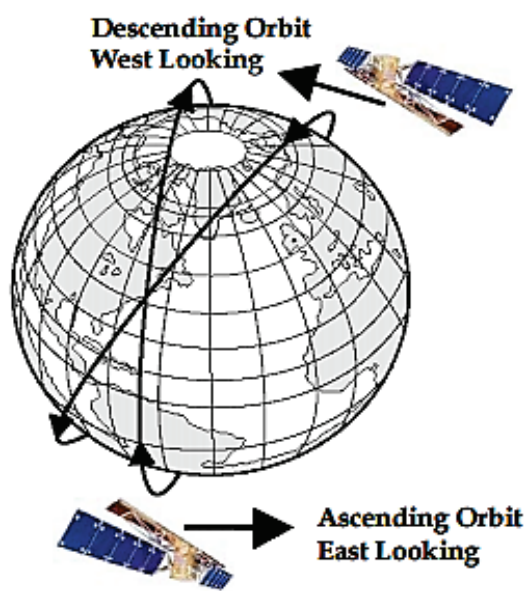

Figure 6 Ascending and descending satellite orbits [19]

Data acquired by SAR acquisitions are first stored on the satellite memory, but the memory is limited, thus the gathered spatial data must be transmitted to numerous control stations around the Globe for further data processing and analysis. The gathered data, radar images, contain two important pieces of information concerning backscattered radar signals: amplitudes and phase values. Taking into account that the radar signal's wavelength and phase are in a direct correlation, any change of the signal's wavelength is also expressed as a change of its phase.

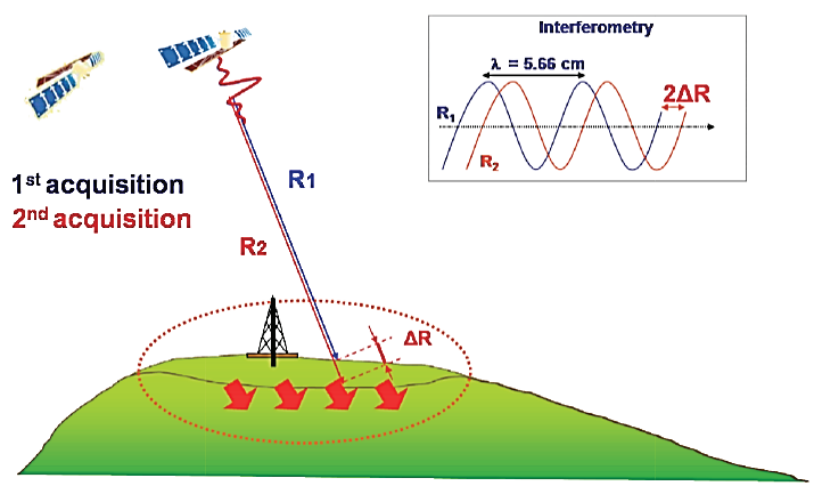

Figure 7 The relationship between a change of electromagnetic signal's phase and ground movement [18]
The SAR interferometry technique measures the phase changes during the exposition time and exploits this to determine the surface ground deformations. When some particular point of the Earth's topography is moving, the distance between that point on ground and satellite is changing, which will also take an effect on the measured phase value of the returned signal. The relationship between that ground point movement and corresponding shift in signal phase between two SAR signals acquired over the same area is depicted in Fig. 7.

The change in signal phase $(\Delta \varphi)$ can be expressed with the following simple equation:

$\Delta \varphi=\frac{4 \pi}{\lambda} \Delta R+\alpha$

where $\lambda$ is the wavelength, $\Delta R$ is the displacement and $\alpha$ is a phase shift due to different atmospheric conditions at the time of the two radar acquisitions. Consequently, any radar target along the satellite line of sight creates a phase shift in the radar signal that can be detected by comparing the phase values of two SAR images acquired at different times [18].

Digital representation of all surface changes derived from the difference of the phase values corresponding to a certain area is an interferogram. Determination of true displacement values from interferometric phases is not a trial task, as interferometric phase values are a blend of different signal contributors.

Interferometric phase is impacted by four contributors: topographic distortions arising from slightly different viewing angles of the two satellite passes $(t)$, atmospheric effects $(\alpha)$ arising from the wavelength distortion that occurs when signals enter and leave a moisture-bearing layer, any range displacement of the radar target $\Delta R$, and noise; range being the distance between the sensor and the target. Therefore, the equation 1 can be extended to more precise form [18]:

$\Delta \varphi=\frac{4 \pi}{\lambda} \Delta R+\alpha+t+$ noise

Process of removing the topographic effect on interferometric phase values is Differential InSAR technique (DInSAR). DInSAR uses a Digital Elevation Models (DEMs) of the area of interest to remove the topographic effects. After the phase contribution due to the local topography is accurately compensated, in 
interferometric phase values are left atmospheric, noise (negligible) and displacements contributors to phase shift.

Following the realization that atmospheric effects on signal phase values were significant, a method emerged in the late 1990's that sought to mitigate this effect by 'averaging' data within multiple interferograms. This process was referred to as Interferogram Stacking. [16] The two most used multi-stacking techniques are Small Baseline Subset (SBAS) and Persistent Scatter (Ps) technique.

\subsection{PsInSAR}

Persistent Scatterer Interferometry (PSI) is the collective term used within the InSAR community to distinguish between single interferogram DInSAR and the second generation of InSAR technologies. The PS technique first appeared in 1999, when the base algorithm was developed at the Politecnico di Milano (Polimi). PsINSAR is an advanced interferometry technique based on the phase shift determination on the permanent scatterers (PSs) of the electromagnetic radiation located on the Earth's surface.

Permanent scatterers are defined as a radar targets, within a resolution cell of radar image, which display stable amplitude properties and coherent signal phase throughout all of the images within a data stack. Objects that make good PS are varied and can be natural or manmade. Among the natural forms are: rock outcrops, hard un-vegetated earth surfaces and boulders. Among the man-made objects are: buildings, street lights, transmission towers, bridge parapets, above-ground pipelines, appurtenances on dams and roof structures and any rectilinear structures that can create a dihedral signal reflection back to the satellite [18].

The main aim of PS technique is to overcome the errors introduced into signal phase values by atmospheric artifacts. That can be accomplished with the identification of PS targets on multiple radar images on which the atmospheric correction procedure can be performed. Minimum required scenes for successful utilization of PS technique are 15 radar images. There is also possibility to perform the technique with smaller radar image stack (especially if the AOI is a mainly urban area) with a good coherence between images but in general it is not recommended. The precision of the technique is better with larger radar data stack as the reliability of the technique's results depends on the number of images used in process. Having removed the atmospheric artifacts with this technique, the displacements on the aforementioned natural and man-made objects can be determined with the accuracy of a few millimeters per year.

\subsection{The application of InSAR technique on the wider Zagreb area}

Satellite Radar Interferometry is implemented in the research to obtain a detail insight into on-going surface deformations occurring in the wider Zagreb area and to enhance previous research findings gathered through the aforementioned GPS geodynamic research. In order to successfully utilize InSAR technique, it is important to know its advantages and disadvantages, topography features and expected surface deformations of the area of interest (AOI). Therefore, it is necessary to have a good preparation phase before the data processing starts.

The application of InSAR technique on the wider Zagreb area (Fig. 8) can be divided into three phases of its realization. Preparation phase is the first phase and it represents a process of finding the right radar images by searching the online databases (archives) and a detail analysis of topography features of the AOI. Second phase is the main phase and it is comprised of two steps: an acquiring of the adequate radar images from institutions responsible for InSAR data dissemination and the processing of the acquired data. Final phase is an analysis of obtained results and a creation of deformation maps.

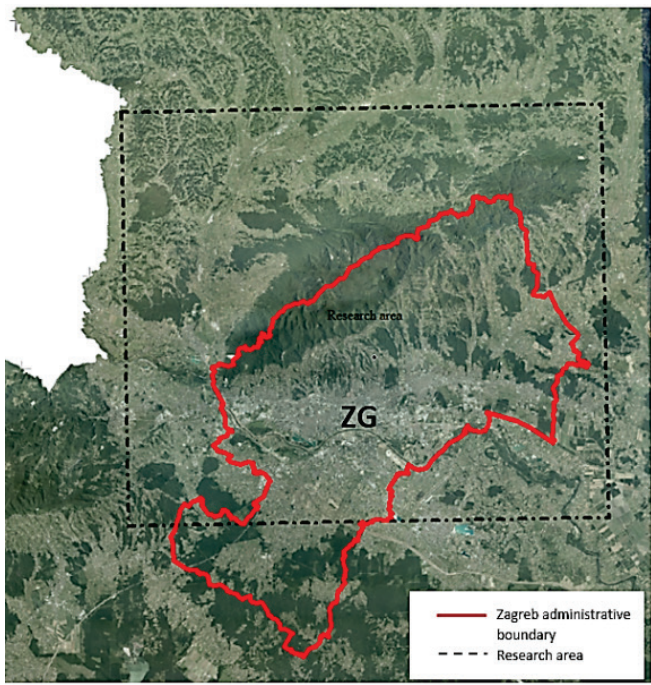

Figure 8 Area of the research (the wider Zagreb area)

Radar images can be obtained from the institutions such as European Space Agency (ESA), German Aerospace Center (DLR), Canadian Space Agency and others, by ordering archived data or by requesting future data acquisitions of AOI. The archived data are only available for certain areas investigated in the past as SAR data acquisitions mainly depend on user demands. Also, there are certain requirements that SAR observations need to fulfill for interferometric applications such as perpendicular and temporal baseline restrictions, which are important for data processing and thereby selection of right radar images. Number of adequate radar images for interferometric processing available over the wider Zagreb area are: 21 images of ERS1, 148 images of ERS2, 59 images of Envisat-ASAR, 260 images of Radarsat 2 and 69 images of Sentinel 1.

Taking into account the good temporal coverage of GPS campaigns on the Geodynamic GPS Network of the City of Zagreb for the period of 2004 to 2009, it was decided to use that period for an investigation of InSAR usability over the wider Zagreb area. Moreover, GPS campaigns were conducted once per every year which ensured good temporal coverage of ongoing ground displacements over the AOI and also mitigated the additional space for interpolation. That enabled the possibility to combine the two independent geodetic techniques, InSAR and GPS for the same research period. Therefore, after finding all available radar data for an interferometric processing over the AOI, it was decided to 
use Enivisat satellite mission and its 40 radar images over the Zagreb area for the aforementioned time span.

Both orbit directions are also considered to ensure the maximum spatial coverage of the area by bypassing the shadowing effect of Medevednica Mountain in the data acquisitions. Therefore, the acquired data for the realization of the research were: 23 Enivsat ASAR scenes from the track 265 (descending orbit) and 17 Enivsat ASAR scenes from the track 272 (ascending track). Furthermore, Envisat satellite mission ended in 2012, so in the interest of further InSAR investigation over the area the use of some other satellite missions like CosmoSkyMed, Radarsat-2 or Sentinel 1 should be considered.

First phase of the InSAR application ended with a detailed analysis of the data availability and, afterwards, by choosing the right radar images for interferometric processing. The next step was an establishment of the cooperation with the European Space Agency (ESA) in order to acquire the necessary data. ESA recognized the importance of this kind of research in this region by providing the 40 Enivsat ASAR scenes for the purpose of the research.

\subsection{Radar data processing}

Radar data processing was conducted with several scientific software packages developed on different universities. Each software is used in a different phase of data processing due to the inability to conduct the data processing in only one software from the beginning to the end. Moreover, they are scientific software solutions that enable users to adapt or upgrade their source code to their needs.

First step of data processing is focusing the radar images to obtain the single look complex images (SLC). Single look Complex data retains the phase and amplitude information of the original SAR data. They are also corrected for satellite reception errors and include a latitude/longitude positional information. In addition, SLC data retains the optimum resolution and is suitable for interferometric processing [20]. Usually that step can be done in the scientific package ROI-PAC (Repeat Orbit Interferometry Package) developed at the Jet Propulsion Laboratory (JPL) on the Caltech (California Institute of Technology) university, but in the research that step is skipped as ESA directly provided SLC radar data. Furthermore, a process of interferogram creation is conducted in the scientific software package called DORIS (Delft object-oriented radar interferometric software) developed at the TU Delft in Netherland. In the process, DORIS also uses additional software packages, for modeling the path of satellite orbit from precise orbit information (Getorb, TU Delft) and for phase unwrapping process (SNAPHU, Stanford). Phase unwrapping is the reconstruction process of the phase difference in radar data by adding the correct integer multiple of $2 \pi$ to the interferometric fringes [21]. Final phase of processing is conducted in the scientific software StaMPS/MTI (Stanford method for persistant Scatterers/Multi Temporal InSAR) developed at the Stanford University and later on upgraded at the universities: Iceland, Delft and Leeds. StaMPS connects all previous processing phases by taking the final products from the aforementioned software packages and applying the PS algorithm on the unwrapped interferograms. Result is the deformation map that shows the ground displacements in Line-of-Sight direction (LOS).

Other software packages used in the data processing are: ADORE (TU Delft) used for a graphical visualization of relationship between master and slave radar images, SNAP (Sentinel Application Platform) developed by ESA used in the research for obtaining the information about signal polarization, wavelength, date and time of acquisitions, image resolution and other information related to radar images, and Matlab software used as a platform for StaMPS code and for visualization of final products. Process of radar data processing is shown in Fig. 9.

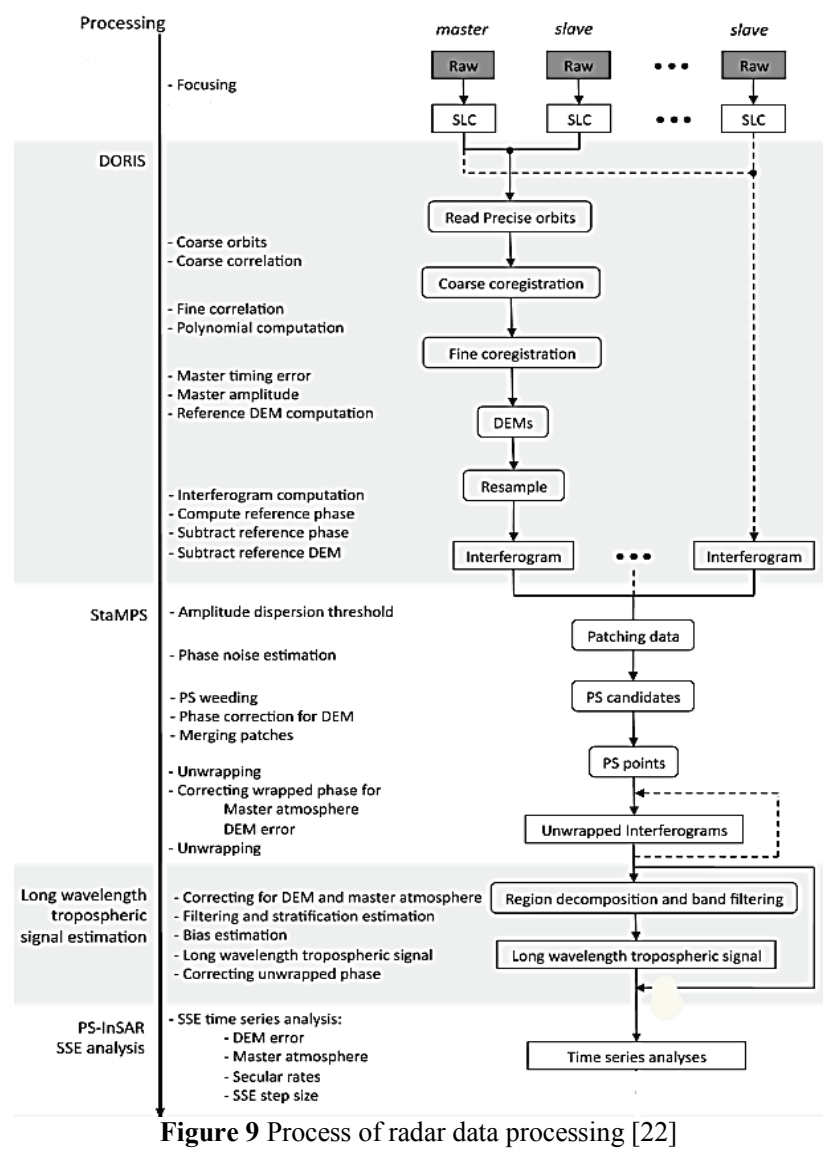

It is important to have the right folder hierarchy according to the source code in software packages. Therfore, before the data processing explained in the aforementioned software packages, the necessary step is to arrange the radar data by grouping them according to the acquisition track (265 and 272) and putting the groups and other relevant data (precise orbit, DEM) in a separate folders. Afterwards, it is essential to select the right master images for the interferometric processing in both groups. Master image is the referent image in the radar data stack, where all other images are called slaves and they are co-registered to the master. That step is carried out with an assistance of software packages SNAP and ADORE. The co-registration step is fundamental in interferogram generation, as it ensures that each ground target contributes to the same (range, azimuth) pixel in 
both the master and the slave image [21]. Co-registration is performed with DORIS in two steps; coarse coregistration and fine co-registration. Coarse coregistration is based on the orbits of slaves and master, and it is computed with an accuracy of about 30 pixels. Result is the coarse offset within a few pixels explained with a simple equation:

$$
P_{\mathrm{s}}(l, p)=P_{\mathrm{m}}(l, p)+o f f \operatorname{set}(l, p),
$$

Where $P_{\mathrm{s}}$ is a slave image, $P_{\mathrm{m}}$ is a master image, $l$ an $p$ are image coordinates (line, pixel). The obtained offset values are then used as initial parameters for the fine coregistration, which is estimated by computing the correlation of the magnitude images for shifts at pixel level [23]. Fine co-registered images are then used as an input for interferogram generation. Generation of the interferogram requires the pixel-to-pixel computation of Hermitian product of two co-registered images shown in Eq. (4) [21]

$$
I=M \times S^{*},
$$

where $M$ and $S$ refer to the master and slave images. Afterwards, on each generated interferogram the phase unwrapping process is performed and the results are used as an input for StaMPS processing. The final step of data processing is an application of PS algorithm on the data stack through which the atmospheric and orbital errors are eliminated from the data. Obtained results are the velocity maps (mm per year) in LOS direction. Furthermore, LOS displacements are displacement vectors regarding to the satellite imaging geometry, hence, they are showing the movement towards or away from the satellite under a certain inclination angle. Therefore, LOS displacement values consist of both horizontal and vertical surface displacements. Number of PS points representing the surface velocity in the AOI per year are: 156898 points from track 265 and 138086 points from track 272.

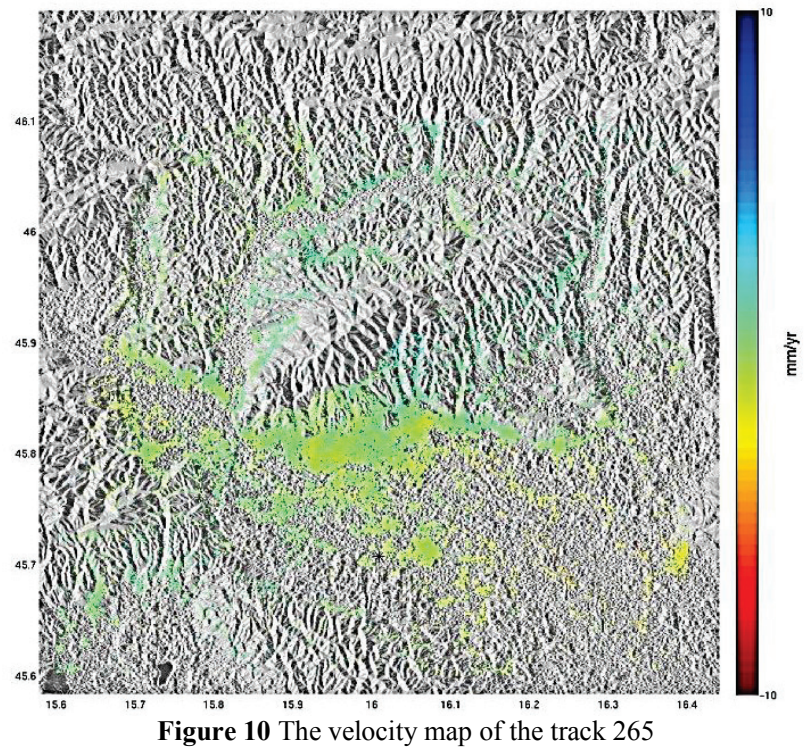

Velocity maps are shown in Figs. 10 and 12, and related maps of standard deviations in Figs. 11 and 13 with the color bar scale from -10 to $10 \mathrm{~mm}$ per year. Furthermore, satellite orbit direction is depicted with the black arrow and LOS direction with the red arrow in the following figures.

Positive velocity values (blue color on the color bar) shown in figures are showing the movement towards the satellite. The area of 200 meters around the asterisk has been considered to be without surface deformations and as such it is taken as the reference point.

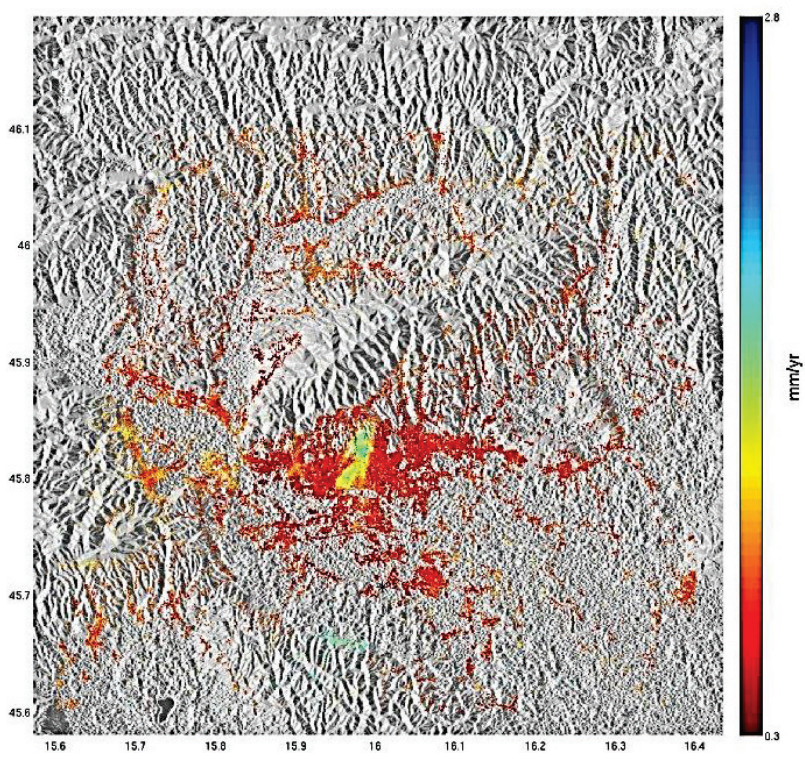

Figure 11 Track 265's map of the standard deviation of the velocity model

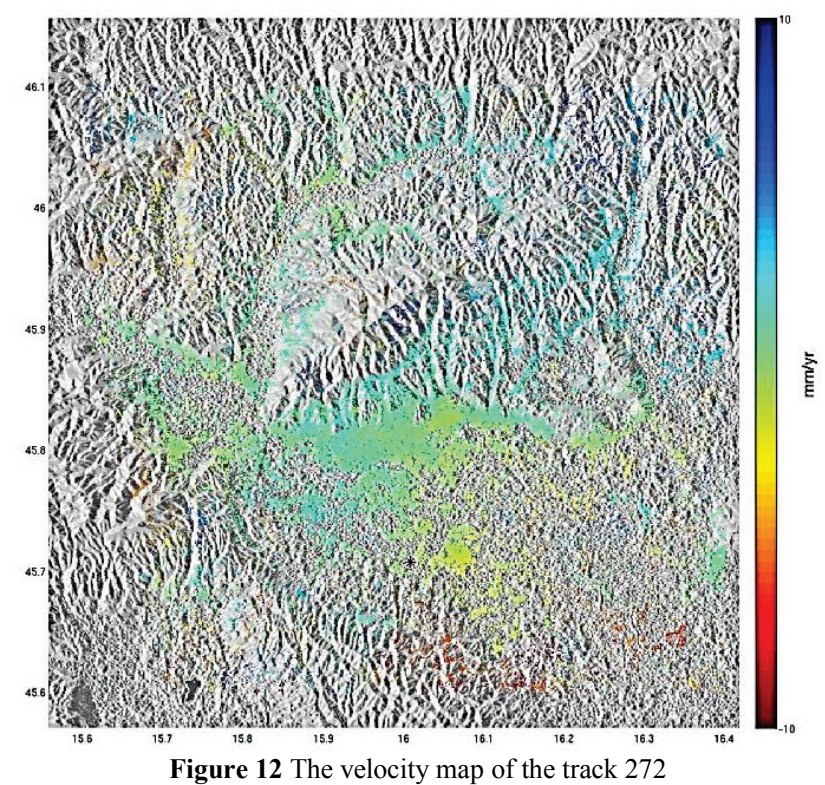

The detail analysis of obtained PS results has shown that the track 265 gave more reliable results than the track 272, which is confirmed by the maps of standard deviations (Figs. 11 and 13) where the maximum standard deviation of track 265 result is $3,9 \mathrm{~mm}$ per year and standard deviation of track 272 result is $8 \mathrm{~mm}$ per year. Reasons can be found in the following, in the data processing of the track 265 more images were used than in track 272 and there were better weather conditions during the SAR acquisitions. The several SAR 
acquisitions of the track 272 were accompanied with rainy weather which is reflected in the obtained results. Obtained results revealed that the average range of surface velocities in the wider Zagreb area is from -2 to 2 mm per year (142230 of 156898 PS points, $90 \%$ ) (Fig. 14) on the velocity map of the track 265 and from -4 to 4 mm per year (129 799 of $138086 \mathrm{pS}$ points, $94 \%$ ) on the velocity map of the track 272 (Fig. 15).

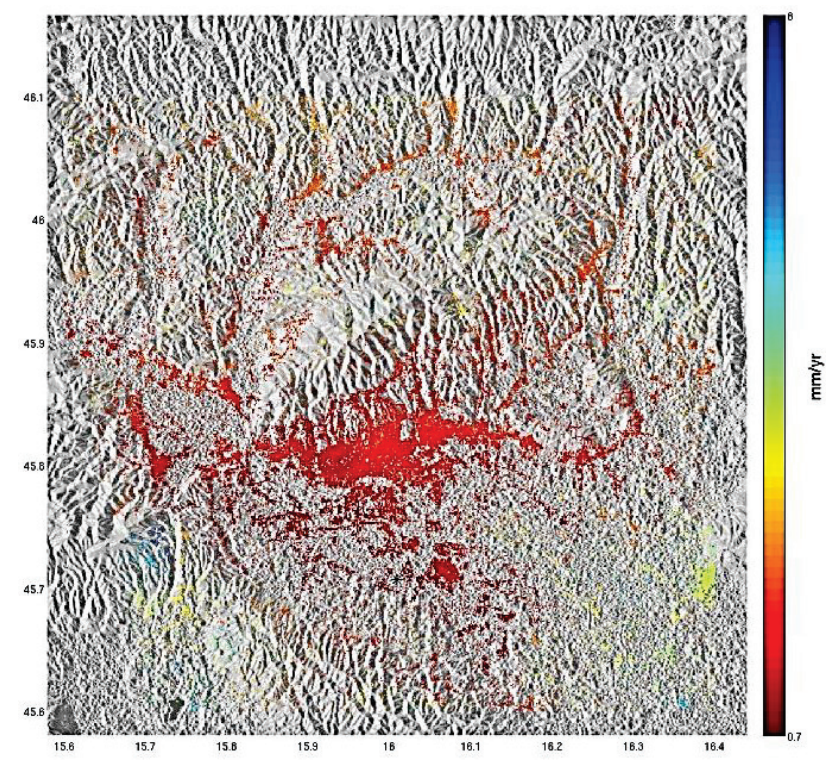

Figure 13 Track 272 's map of the standard deviation of the velocity model

Histogram of T265

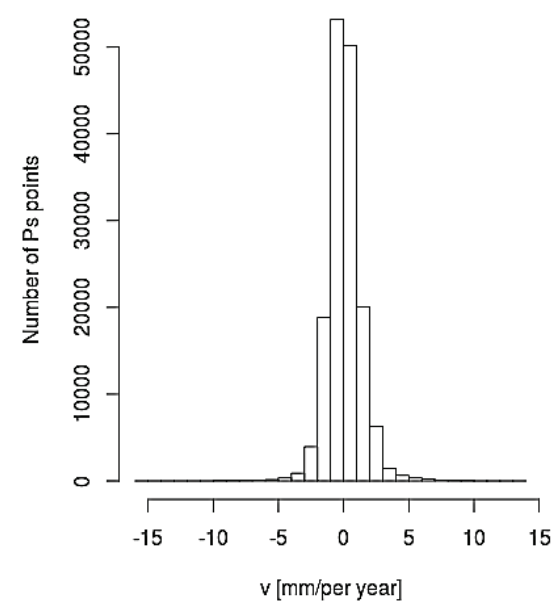

Figure 14 Velocity value distribution on PS points of tracks 265
Histogram of T272

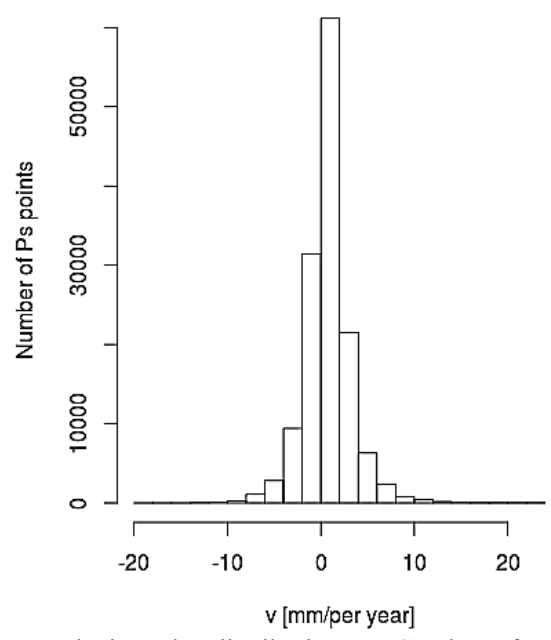

Figure 15 Velocity value distribution on PS points of tracks 272

Detail statistics of the obtained results are shown in Tab. 4. Final results after elimination of gross errors in the results are shown in Tab. 5.

\section{The Combination of GPS and InSAR results}

The combination of GPS and InSAR results has provided a more detail insight in ongoing ground surface deformations in the wider Zagreb area, for the period $2004 \div 2009$. Data gathered through GPS campaigns has ensured the precise determination of horizontal and vertical ground displacements on the discrete points, whereas InSAR provided information of surface displacements on more than 100000 points but in the LOS direction. GPS data has ensured the referent (more accurate) velocity model of the AOI and InSAR provided better coverage of the area, especially in urban parts of the area. Therefore, with the combination of these two techniques, the more accurate and detailed investigation of ongoing geodynamic processes in the area is enabled. The result of the combination of the two independent geodetic techniques for the determination of ground displacements in the AOI is depicted in Fig. 15.

In the combination used there is only InSAR result from the track 265 because it is more reliable than the result from the track 272. Due to the enormous amount of points, the result is shown in Fig. 16 as a surface map. Furthermore, it can be concluded that the InSAR results provided a very dense spatial information about the surface displacements in the urban parts of the area, whereas the highly vegetated areas (Medvednica Mountain) are exposed to interpolation due to the lack of data.

Table 4 Detail statistics of the obtained PS results

\begin{tabular}{|c|c|c|c|c|}
\hline Statistical parameters & $\begin{array}{c}\text { T265 } \\
\text { (velocity mm/year) }\end{array}$ & $\begin{array}{c}\text { T265 } \\
\text { (std of velocity mm/year) }\end{array}$ & $\begin{array}{c}\text { T272 } \\
\text { (velocity mm/year) }\end{array}$ & $-18,67$ \\
\hline Min & $-15,24$ & 0,21 & $-0,45$ \\
\hline $1^{\text {st }} \mathrm{Qu}$ & $-0,65$ & 0,60 & 0,73 & 0,38 \\
\hline Median & 0,01 & 0,76 & 0,75 & 1,53 \\
\hline Mean & 1,07 & 0,83 & 1,98 \\
\hline $3^{\text {rd }} \mathrm{Qu}$ & 0,72 & 0,97 & 2,24 \\
\hline Max & 13,05 & 3,91 & 2,71 \\
\hline
\end{tabular}


Table 5 Final PS results after elimination of gross errors in the results

\begin{tabular}{|c|c|c|c|c|c|c|c|}
\hline Track id. (velocity map) & $\begin{array}{c}\text { Number of PS } \\
\text { points }\end{array}$ & $\begin{array}{c}\text { Min } \\
(\mathrm{mm} / \text { year })\end{array}$ & $\begin{array}{c}1^{\text {st }} \mathrm{Qu} . \\
(\mathrm{mm} / \text { year })\end{array}$ & $\begin{array}{c}\text { Median } \\
(\mathrm{mm} / \text { year })\end{array}$ & $\begin{array}{c}\text { Mean } \\
(\mathrm{m} / \text { year })\end{array}$ & $\begin{array}{c}3^{\text {rd }} \text { Qu. } \\
(\mathrm{mm} / \text { year })\end{array}$ & $\begin{array}{c}\text { Max } \\
(\mathrm{mm} / \text { year })\end{array}$ \\
\hline $\begin{array}{c}\text { T265 (max std of } 1 \\
\text { mm/per year) }\end{array}$ & 121490 & $-6,82$ & $-0,65$ & $-0,03$ & $-0,01$ & 0,60 & 9,42 \\
\hline $\begin{array}{c}\text { T272 (max std of } 2,5 \\
\text { mm/per year) }\end{array}$ & 95530 & $-18,67$ & $-0,48$ & 0,55 & 0,39 & 1,35 & 14,24 \\
\hline
\end{tabular}

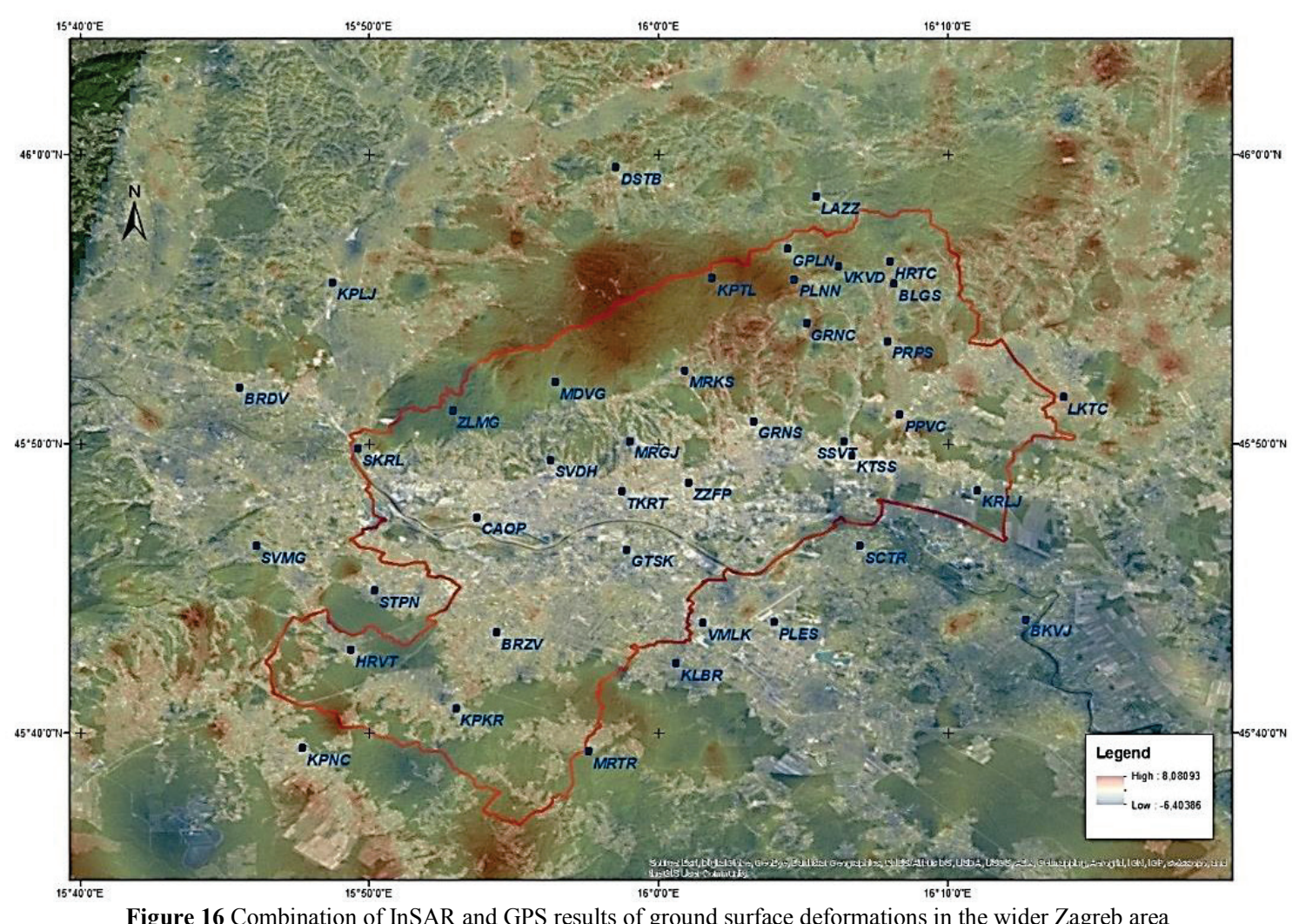

Figure 16 Combination of InSAR and GPS results of ground surface deformations in the wider Zagreb area

\section{Conclusion}

The geodynamic research in the wider Zagreb area started in 1997 with the project "Geodynamic GPS Network of the City of Zagreb" and, since then, 10 GPS campaigns have been conducted on the network points with the aim to determine the geodynamically induced ground deformations in the area. The research has revealed so far that the average velocity values on the network points are $1,72 \mathrm{~mm}$ per year in horizontal direction and 5,17 $\mathrm{mm}$ per year in vertical direction.

The next logical step in the research was to enhance the aforementioned research with InSAR (Interferometric Synthetic Aperture Radar) technique in order to obtain a more detail insight of ongoing ground deformations. That was enabled by European Space Agency (ESA) in 2015, when they provided 40 Enivsat ASAR radar images. The radar data was processed with an advanced multi-stacking Persistent Scatteres (PS) technique in StaMPS scientific software package. PS algorithm has shown to be extremely efficient in urban parts of the research area, where a highly dense and reliable surface velocity model is obtained. The model represents surface displacements mainly in the vertical direction, which can be useful for monitoring stability of buildings in the city.

Final deliverables from the InSAR data processing were two surface velocity maps showing the average surface displacements per year, in Line-of-Sight direction.
Obtained surface displacements are determined on the 156898 PS points from track 265 and 138086 PS points from track 272. After a detailed analysis of the surface velocity maps it is evident that the ranges of surface displacements from the InSAR data are: -2 to $2 \mathrm{~mm}$ per year on the velocity map of track 265 and from -4 to 4 $\mathrm{mm}$ per year on the velocity map of track 272 .

The utilization of InSAR data in the research was conducted for the period from to 2004 to 2009 , due to the good temporal coverage of GPS campaigns. That ensured the possibility to combine these two independent geodetic techniques on a reliable level. GPS data ensured the more accurate velocity model of the area determined from 40 discrete network points, whereas InSAR data provided a better coverage of the area, especially in urban parts of area. The combination of these two techniques gave a more accurate and detailed insight into ongoing surface and geodynamic processes in the wider Zagreb area.

\section{Acknowledgments}

We would like to thank the European Space Agency (ESA) for their support and for the data supplied for this research. We would also like to acknowledge the contribution of the universities where the software packages used in the research were developed. Furthermore, we appreciate the free accessibility of the aforementioned software packages. 


\section{References}

[1] Pribičević, B.; Medak, D.; Đapo, A. Densification of the Zagreb Geodynamic Network in the area of northeast Medvednica. // Geodetski list. 61(84), 4(2007), pp. 247 258.

[2] Pribičevic, B.; Đapo, A.; Medak, D. Geodetic-Geologic Research on Wider Zagreb area based on Geodynamic Network of the City of Zagreb. // Geodetski list. 65(88), (2011), pp. 1-19.

[3] Pinter, N; Grenerczy, G.; Webber, J.; Stein, S.; Medak, D. (Eds.) The Adria Microplate: GPS Geodesy. // Tectonics and Hazards, Vol. 61. Veszprem, Hungary: Springer, (2004).

[4] van Gelder, I. E.; Matenco, L.; Willingshofer, E.; Tomljenović, B.; Andriessen, P. A. M.; Ducea, M. N.; Beniest, A.; Gruic, A. The tectonic evolution of a critical segment of the Dinarides-Alps connection: Kinematic and geochronological inferences from the Medvednica Mountains, NE Croatia. // Tectonics. 34, (2015). DOI: $10.1002 / 2015 \mathrm{tc} 003937$

[5] Matoš, B.; Tomljenović, B.; Trenc, N. Identification of tectonically active areas using DEM: a quantitative morphometric analysis of Mt. Medvednica, NW Croatia. // Geological quarterly. 58, 1(2014), pp. 51-70. DOI: 10.7306/gq. 1130

[6] Herak, D.; Herak, M.; Tomljenović, B. Seismicity and earthquake focal mechanisms in North-Western Croatia. // Tectonophysics. $\quad 485$, (2009), pp. 212-220. DOI: 10.1016/j.tecto.2008.12.005

[7] Herak, M.; Allegretti, I.; Herak, D.; Ivančić, I.; Kuk, K.; Marie, K.; Markušić, S.; Sović, I. Seismic hazard maps of Croatia. // Geophysical Challenges of the 21st century Zagreb, (2011), (poster) Zagreb, Croatia.

[8] Đapo, A.; Pribicević, B.; Medak, D.; Prelogović, E. Correlation between Geodetic and Geological Models in the Geodynamic Network of the City of Zagreb. // Reports on Geodesy. 86, (2009), pp. 115-122.

[9] Herring, T.; Davis, J.; Shapiro, I. Geodesy by radio astronomy: the application of Kalman filtering to Very Long Baseline Interferometry. // J. Geophys. Res. 95, (1990), pp. 12561-12581. DOI: 10.1029/JB095iB08p12561

[10] Dong, D.; Herring, T.; King, R. Estimating regional deformation from a combination of space and terrestrial geodetic data. // Journal of Geodesy. 72, 4(1998), pp. 200214. DOI: $10.1007 / \mathrm{s} 001900050161$

[11] Herring, T. A.; King, R. W.; Floyd, M. A.; McClusky S. C. GAMIT - GPS Analysis at MIT, Reference Manual 10.6. Department of Earth, Atmospheric, and Planetary Sciences Massachusetts Institute of Technology. 2015.

[12] Reilinger, R.; McClusky, S.; Vernant, P.; Lawrence, S.; Ergintav, S.; Cakmak, R.; Ozener, H.; Kadirov, F.; Guliev, I.; Stepanyan, R.; Nadariya, M.; Hahubia, G.; Mahmoud, S. K.; Ar-Rajehi, S. A.; Paradissis, D.; Al-Aydrus, A.; Prilepin, M.; Guseva, T.; Evren, E.; Dmitrotsa, A.; Filikov, S. V.; Gomez, F.; Al-Ghazzi, R.; Gebran K. GPS Constraints on Continental Deformation in the AfricaArabia-Eurasia Continental Collision Zone and implications for the Dynamics of Plate Interactions. // Journal of Geophysical Research. 111 (B05411), (2006). DOI: 10.1029/2005jb004051

[13] McClusky, S.; Balassanian, S.; Barka, A.; Demir, C.; Ergintav, S.; Georgiev, I.; Gurkan, O.; Hamburger, M.; Hurst, K.; Kahle, H.; Kastens, K.; Kekelidze, G.; King, R.; Kotzev, V.; Lenk, O.; Mahmoud, S.; Mishin, A.; Nadariya, M.; Ouzounis, A.; Paradissis, D.; Peter, Y.; Prilepin, M.; Reilinger, R.; Sanli, I.; Seeger, H.; Tealeb, A.; Toksöz, M. N.; Veis, G. Global Positioning System constraints on plate kinematics and dynamics in the eastern Mediterranean and
Caucasus. // Journal of Geophysical Research. 105, (2000). DOI: 10.1029/1999jb900351

[14] Davies, P.; Blewitt, G. Methodology for global geodetic time series estimation: A new tool for geodynamics. // Journ. Geophys. Res. 105, 11(2000), pp. 11083-11100. DOI: 10.1029/2000JB900004

[15] Lavallee, D.; Blewitt, G.; Clarke, P. J.; Nurutdinov, K.; Holt, W. E.; Kreemer, C.; Meertens, C. M.; Shiver, W. S.; Stein, S.; Zerbini, S.; Bastos, L.; Kahle, H. G. GPSVEL Project: Towards a Dense Global GPS Velocity Field. // Proceedings of the International Association of Geodesy Scientific Assembly, Budapest, (2001).

[16] Dawson, J. H. Satellite Radar Interferometry with Application to the Observation of Surface Deformation in Australia, The Australian National University (PhD thesis), (10.2008)

[17] SarMAPSARscape, SAR Guidebook. http:// www.sarmap.ch/pdf/SAR-Guidebook.pdf (10.08.2016)

[18] RiskNET, Interferometric Synthetic Aperture Radar, an Introduction for Users of InSAR Data. http://www.risknetalcotra.org/rna/allegati/insar-manual-20101008_468.pdf (10.08.2016)

[19] U.S. Department of Transportation, Federal Highway Administration InSAR Applications for Highway Transportation Projects, Publ. No. FHWA-CFL/TD-06-002, (04.2006)

[20] National University of Singapore, The Centre for Remote Imaging, Sensing and Processing: Radarsat products. https://crisp.nus.edu.sg/rsat/rsat prod.html (09.08.2016)

[21] European Space Agency, InSAR processing: A practical approach. $\quad$ http://www.esa.int/esapub/tm/tm19/TM19 ptB.pdf (09.08.2016)

[22] Bekaert, D. InSAR time series analysis of the 2006 slow slip event on the Guerrero Subduction Zone, Mexico, Delft University of Technology, Faculty of Aerospace Engineering, Delft Institute of Earth Observation and Space Systems (master thesis), (26.12.2010)

[23] TU Delft, DORIS user manual and technical documentation http://doris.tudelft.nl/software/doris_v4.02.pdf (09.08.2016)

\section{Authors' addresses}

Prof. Boško Pribičević, PhD

University of Zagreb, Faculty of Geodesy, Dept. of Geomatics, Kaciceva 26, 10000 Zagreb, Croatia

E-mail: bpribic@geof.hr

\section{Assist. Prof. Almin Đapo, PhD}

University of Zagreb, Faculty of Geodesy, Dept. of Geomatics, Kaciceva 26, 10000 Zagreb, Croatia

E-mail: adapo@geof.hr

\section{Marin Govorčin, mag. ing. geod. et geoinf.}

University of Zagreb, Faculty of Geodesy, Dept. of Geomatics, Kaciceva 26, 10000 Zagreb, Croatia

E-mail: mgovorcin@geof.hr 